\title{
Correspondence
}

\section{Aboriginal myth meets DNA analysis}

DNA analysis of the Australian outback's only palm tree,

Livistona mariae, indicates that it originated from seeds brought from the north of the country - a finding backed up by a recently unearthed Aboriginal myth. This neatly illustrates how traditional ecological knowledge might inform modern research.

Known as the cabbage palm and found only in Palm Creek, L. mariae (pictured) diverged between 7,000 and 31,000 years ago from its relative Livistona rigida, found 1,000 kilometres to the north (see Nature 483, 248; 2012). Because these dates overlap with human occupancy, the study concluded that the seeds could have been transported south and planted in central Australia (T. Kondo et al. Proc. R. Soc. B http://doi.org/2w6; 2012).

The Aboriginal myth came to our attention through a 2013 translation of an 1895 text by German anthropologist and missionary Carl Strehlow (see go.nature.com/kxfyvn). He wrote of a visit to Palm Creek: "There are beautiful 40 to 50 feet high palms here surrounded by gum trees and acacias and the herbs and flowers at their base release a sharp smell. How this palm got into the interior of Australia has not been established yet by science." Strehlow relates that, according to traditional local beliefs, "the gods from the high north brought the seeds to this place a long time ago".

David M. J. S. Bowman University of Tasmania, Australia. Jason Gibson Museum Victoria, Melbourne, Victoria, Australia. Toshiaki Kondo Hiroshima University, Japan. david.bowman@utas.edu.au

\section{US Congress replies on NSF scrutiny}

As chairman of the US House Committee on Science, Space, and Technology, I do not

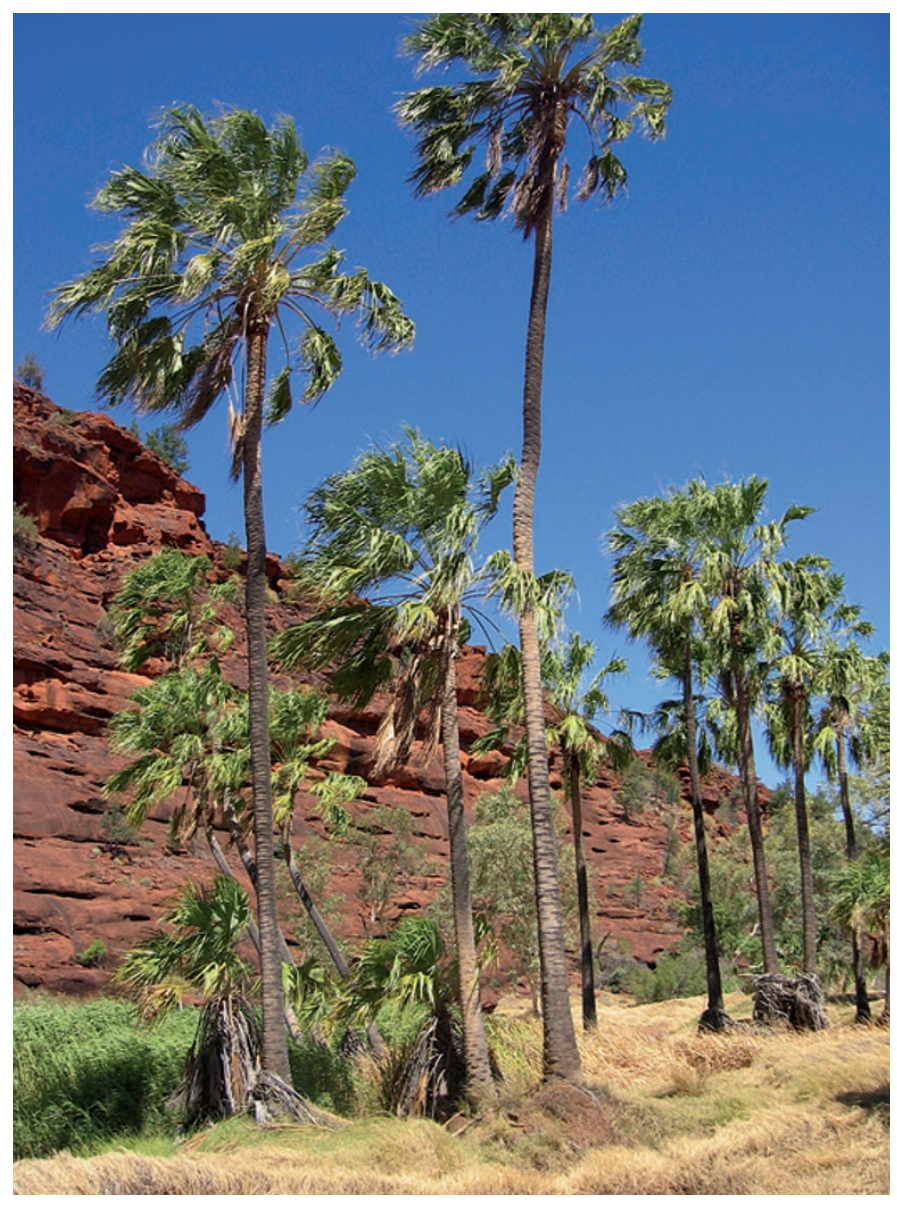

A. L. Mitchell Water Resources Res. 11, 493-495; 1975), they could accumulate in soils and sediments and then enter biological concentration processes, disrupting ecosystems (C. Franke et al. Chemosphere 29, 1501-1514; 1994). The film coating reduces the water's surface tension, interfering with floating plants, pollen transport and insect egg-laying. It has a heating effect that could alter flux between water layers, disturbing solutes and habitats.

Hydrophobic airborne pollutants, including particles of black carbon, will be attracted to the films, potentially changing the surface's reflectivity (albedo) and contributing to climate change.

We should learn from previous ill-judged large-scale chemical applications and ensure that the necessary safety tests and regulatory measures are in place first.

Guohe Huang North China

Electric Power University, Beijing, China.

Yao Yao University of Regina, Saskatchewan, Canada. huang@iseis.org

believe that you do justice to the committee's efforts to better understand how the US National Science Foundation (NSF) spends US $\$ 7$ billion dollars of taxpayers' money (Nature 519, 138-139; 2015).

The NSF is not "caught between the scientists it serves and the lawmakers it answers to". The money is not the NSF's or the scientists': it is the people's. Congress has a responsibility to ensure that the money is spent wisely and in the national interest.

As you point out, NSF director France Córdova has voiced her support for my proposal that research should be in the national interest if it is to be funded by the NSF. At a recent hearing of the House science committee, she declared the proposal to be "very similar and compatible with NSF's internal guidelines" (see go.nature.com/oywlbd).
Significant progress has also been made on the need for extra transparency and accountability at the NSF. Its new policy acknowledges the need for the agency to communicate clearly and describe research grant awards in non-technical terms. Lamar Smith House of Representatives, Washington DC, USA.

tx21ima@mail.house.gov

\section{Evaluate risks of coating reservoirs}

The environmental effects of chemical films that reduce evaporation of water from reservoirs should be properly evaluated before the films are applied on a large scale (Nature 519, 18-19; 2015).

For example, when these films are driven by waves towards the shoreline (F. R. Crow and

\section{Laboratory work is 'like falling in love'}

Kevan Martin's obituary of neuroscientist Vernon Mountcastle (Nature 518, 304 ; 2015) nicely conveys the intensity of his passion for experimental work. This was eloquently expressed in a letter he sent to me on his retirement from the bench.

Mountcastle wrote: "I miss laboratory work in a way that is difficult to describe. It has always been my heart's joy, and my own experience has always been that even the most trivial original discovery of one's own evokes a special kind of ecstasy - it is almost like falling in love for the first time, all over again!" Oliver Sacks New York University School of Medicine, New York, USA. mail@oliversacks.com 